\title{
Jaša Drnovšek \\ Early Modern Religious Processions: The Rise and Fall of a Political Genre
}

\begin{abstract}
Es ist Schande zu sagen - selbst seynwollende Katholiken werfen sich jetzt als Reformatoren auf, unterfangen sich ihre heilige Mutter, die christkatholische Kirche zu hofmeistern, und besonders ihre äußerliche Pracht, ihre Zeremonien und Feyerlichkeiten, als lauter Mißbräuche und Gauckelwerke, mit Mund und Feder zu beschnarchen und auszuzischen. [...] Ihr, meine Geliebtesten! Haltet euch unerschüttert an die alten Gewohnheiten und löblichen Gebräuche unserer christkatholischen Religion. [...] - Lasset euch doch von keinem Quacksalber, und Marktschreyer, von keinem heutigen Afterphilosophen - neue Begriffe von Gottesverehrung beybringen. Sie sind Leute eines gebrandmarkten Gewissens, Feinde der Religion, und der wahren Kirche, Selbstdenker, und Modewitzler, die eben so wenig zum Unterrichte des christlichen Volkes, als der Esel zum Lautenschlagen, berufen sind. ${ }^{1}$
\end{abstract}

It is a shame to say - even self-professed Catholics are acting up as reformers now, they dare to instruct their holy mother, the Catholic Church, and especially to criticize and hiss down, by tongue or pen, its external splendor, its ceremonies and festivities, as pure abuse and jugglery. [...] My dearest ones! Stick unbroken to the old habits and laudable customs of our Catholic church. [...] - Do not let any quack doctor, any market barker, any false philosopher of today - teach you new concepts of worshipping the Lord. These people have a corrupted conscience, they are enemies of religion, and of the true Church, self-thinkers, and modish wags, who are as little qualified to teach the Christian people as a donkey is to play the lute.

These highly passionate words, at once beseeching and despairing, belong to Albert Komploier, a Capuchin friar from Tyrol, who in the second half of the eighteenth century and the first decade of the nineteenth served as a preacher in the parishes of Brixen/Bressanone and Bozen/Bolzano. The passage is part of a sermon that he most likely gave during the last two decades of the eighteenth century and which he published in 1803 in a collection entitled Das zerfallene Christenthum am Ende des achtzehnten Jahrhunderts oder Sonn- und Festpredigten wider die herrschenden Modelaster, falschen Grundsätze und

1 Albert Komploier. "Auf das Fest des allerheiligsten Fronleichnams: Schutzrede für die Fronleichnamsprozeßion, und andere kirchliche Ceremonien.” Das zerfallene Christenthum am Ende des achtzehnten Jahrhunderts oder Sonn- und Festpredigten wider die herrschenden Modelaster, falschen Grundsätze und Scheintugenden unserer Zeiten. Augsburg: Veith, 1803, vol. 2, pp. 164-179; p. 165, pp. 177 f. 
Scheintugenden unserer Zeiten. In the second edition of the book, however, which was printed posthumously in 1846 and bears the significant addition "in zeitgemäßer Bearbeitung" ("updated version") on the first page, the appeal quoted above was radically changed: "Quacksalber" ("quack doctor") and "Marktschreyer" ("market barker") from the first edition of the book, for instance, were replaced by "Modeweise" ("modish wise men"), while "Afterphilosoph" ("false philosopher") was changed to "Aufklärer"2 ("proponent of the Enlightenment"). In other words, the second edition attributes some sort of subtlety and craftiness in relation to the detractors of the Church.

In order to understand the aggressiveness, even ribaldry of Komploier's first version of the sermon, one needs to consider the great mental shift that affected the Catholic Church from the second half of the eighteenth century onward. It was precisely the 'false philosophy,' as Komploier had put it, the Enlightenment spirit, that provoked great and concrete political changes. In Austria, for instance, a church reform, started by the Empress Maria Theresia and continued by her son Joseph II, curbed the autonomy of the Church and diminished its political influence. Among other things, tax liability for the clergy was introduced; religious orders that were not considered economically productive, that is, not involved in charitable, educational, or other social activities, were abolished, and the number of their monasteries and convents was reduced; and, last but not least, a considerable number of religious festivals were banned, either, again, due to alleged economic reasons, or because the piety that manifested itself in such events was henceforth declared a "superstition." ${ }^{3}$ When Komploier talks of ceremonies, he is thinking first and foremost of religious processions. Historically, these fall into a long line of Christian tradition that began in late antiquity. ${ }^{4}$ However, it was not by accident that their golden age coincided with the age of the Counter-Reformation and Catholic renewal. In fact, in this period religious processions are often affiliated with

2 Albert Komploier. "Fronleichnamsfest. Widerlegung der Einwendungen gegen die Fronleichnamsfeier und andere kirchliche Ceremonien.” Das zerfallene Christentum am Ende des achtzehnten Jahrhunderts. Sonn- und Festtagspredigten wider die herrschenden Modelaster, falschen Grundsätze und Scheintugenden unserer Zeiten. 2nd rev. ed., Lindau: Stettner, 1846, vol. 2, pp. 28-36; p. 35.

3 Significantly, the Enlightenment, according to Immanuel Kant, is nothing other than "[1]iberation from superstition” (Immanuel Kant. Critique of Judgement. Translated by Werner S. Pluhar. Indianapolis: Hackett, 1987, p. 161.).

4 One of the earliest recorded accounts of such processions appears in a fourth-century manuscript, the Itinerarium Aetheriae, written by a Galician woman who traveled to the Holy Land in about 381-384 (see Egeria's Travels, translated and edited by John Wilkinson. Oxford: Aris \& Phillips, 1999). 
two religious institutions that have been called "emblematic orders of the Catholic renewal:"5 the order of Capuchin Friars Minor, and the Society of Jesus.

As different as these two orders may seem, they share at least three common traits that enabled them to become a new part of the clerical elite. First, at the time of the Council of Trent (1545-1563), when the process of the CounterReformation and Catholic renewal formally started, they were - or, at least, they figured as - new political players, carrying no baggage from the old Church; the Capuchins were established in 1528, while the Jesuits got their papal approval in $1540 .{ }^{6}$ Second, from their very beginnings both orders distinguished themselves through a remarkably high mobility, which allowed them to build and maintain wide political networks. Third, numerous pastoral practices of these "mobilizers,"7 including the staging of religious processions, coincided with the political views of the Tridentine Church.

One of the first documented processions, held by the Capuchins, was a penitential procession that took place on a hill near Montepulciano in Tuscany in the summer of 1539. Interestingly, it is described in a letter written by one of the very first Jesuits, Francisco Strada, addressed to the founder of the order, Ignatius de Loyola. Strada reports the following scene:

[V]i venir una proçesión de çerca de treçientos niños desnudos y disciplinándose, los quales, como verdaderos soldados, seguían al capitán Xpo. crucifixo, el qual en lugar de bandera uno delante [de] todos llevava, cantando todos las letanías, y de poco en poco alta voçe exclamando: Misericordia, misericordia.

Después desto, [...] se comineza á ordenar de comer, y los [...] capuchinos [...] salían [...] con unos canjstros de pedazos de pan, que [...] distribuyan por los niños, que de diçiplinarse cansados estavan. ${ }^{8}$

I saw a procession of some three hundred naked children who were flagellating themselves, following like true soldiers their commander, Christ on the cross. He was borne by a child, instead of a flag, before all the others. All the while, the children were singing litanies and, from time to time, they would exclaim loudly: Mercy! Mercy! Afterwards [...] one was invited to have a meal and the [...] Capuchins [...] appeared [...] with some baskets

5 Ronnie Po-chia Hsia. The World of Catholic Renewal: 1540-1770. Cambridge: Cambridge University Press, 1998, p. 31.

6 Strictly speaking, the Capuchins were not an entirely new order in 1528 . They had evolved from the Observants, one of the two branches of the Franciscan order (see Father Cuthbert. The Capuchins: A Contribution to the History of the Counter-Reformation. London: Sheed \& Ward, 1928, pp. 85-120.).

7 Stephen Greenblatt. “A mobility study manifesto.” Cultural Mobility: A Manifesto, edited by Stephen Greenblatt. Cambridge: Cambridge University Press, 2009, pp. 250-253; p. 251.

8 Francesco Strada. "To Ignatius de Loyola." 5 July 1539. I frati cappuccini: Documenti e testimonianze del primo secolo, edited by Costanzo Cargnoni. Perugia: EFI, 1988, pp. 321-325; pp. $322 \mathrm{f}$. 
of bread, which [...] was given to the children, who were exhausted from flagellating themselves.

As plain as the procession depicted by Strada seems in its concept, it must have left a strong physio-psychological impact on its spectators. On the one hand, they could observe the penance in its most radical form, as mortification of the flesh. Since this was carried out by children, symbolic agents of innocence and purity, we can assume that the moral, pedagogical effect of the scene was accordingly intensified. In fact, Strada reports that the parents of the selfflagellating children were "confusos que los niños le enseñasen lo que ellos havian de hazer, se determjnaron de reformarse"9 ("baffled as the children taught them what they themselves should do, [and] they decided to improve"). At the same time, however, one cannot miss the overall impression the procession left on Strada. He himself talks of "milagros"10 ("wonders"). Considering the soldierly rhetoric he uses to describe the scene, and imagining children whipping themselves, singing, and shouting unanimously while marching lined up behind the moving statue of Christ, it must have been a highly unusual, yet not in the least repellent demonstration - and at the same time a production of power. ${ }^{11}$

As I have already mentioned, such religious processions were perfectly in tune with the politics of the Tridentine Church. In fact, its readiness to support such performances can already be traced in the decrees of the Council of Trent. For instance, in the decree entitled "On the invocation, veneration, and relics of saints, and on sacred images," one reads that "great profit is derived" from mimetic "representations" of the "mysteries of our Redemption," since they make people "excited to adore and love God, and to cultivate piety." 12 In addition, in the "Decree concerning the most holy sacrament of the eucharist," a fairly direct instruction is given, namely that in a procession to be held on the Feast of Corpus Christi, "truth" should "celebrate a triumph over falsehood and heresy," and "her adversaries [...] may either pine away weakened and broken; or, touched with shame and confounded, at length repent." ${ }^{13}$ Considering this, it can be no coincidence that religious processions held by the Capu-

9 Ibid., p. 324.

10 Ibid., p. 325.

11 Power is here understood in the terms of Max Weber (see Economy and Society: An Outline of Interpretive Sociology. New York: Bedminster Press, 1968, p. 926.).

12 "On the invocation, veneration, and relics of saints, and on sacred images." The Council of Trent: The Canons and Decrees of the Sacred and Oecumenical Council of Trent, translated and edited by James Waterworth. London: Dolman, 1848, p. 232.

13 "Decree concerning the most holy sacrament of the eucharist." Ibid., p. 79. 


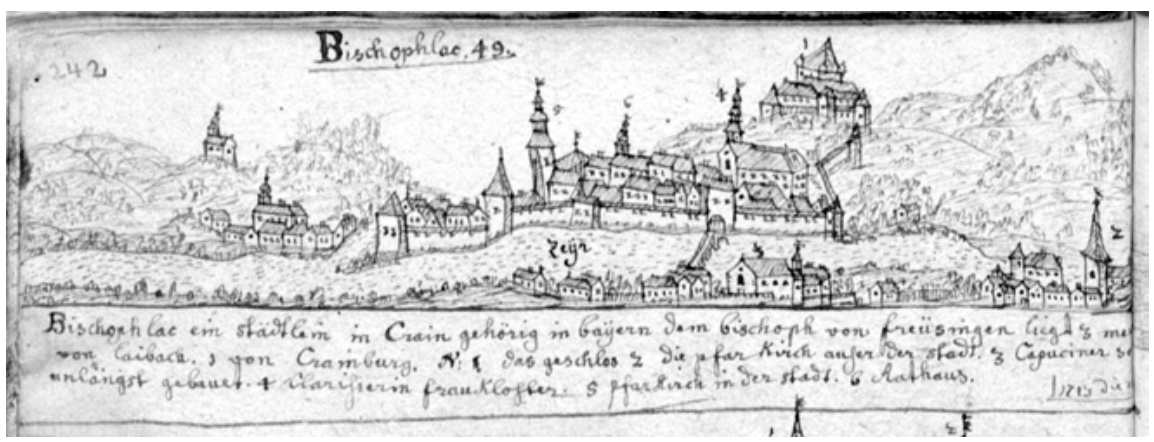

Fig. 1: A drawing of the town of Škofja Loka from 1713. Oberösterreichisches Landesarchiv, Neuerwerbungen, Handschrift 140.

chins or the Jesuits began to flourish at the end of the sixteenth century. By then, most of the Council's decrees had not only been confirmed by the pope, but had also largely been put into practice. ${ }^{14}$

Aside from the Corpus Christi processions, which are explicitly encouraged in the decrees, another type of procession started to evolve in that period: the Good Friday processions. Like the procession Francisco Strada observed in Tuscany some forty years earlier, these processions were penitential in their character, too, and they would have provoked similar psycho-physiological effects in the spectators. Their production dimension, however, was much more sophisticated, and only kept growing during the next two centuries. If the initial Good Friday processions consisted of penitents who whipped themselves while marching solemnly through the streets, this initial phase was soon exceeded. Instead of penitents, it was laymen representing characters or dramatic scenes from the Passion of Christ who formed the core of these annual reenactments. ${ }^{15}$ From this moment on, Good Friday processions can also be considered passion processions or passion procession plays. ${ }^{16}$

One of the best illustrations of what Good Friday processions looked like when fully developed is offered by the processions in the Slovenian town

14 See Hubert Jedin. "Das Papsttum und die Durchführung des Tridentinums (1565-1605)". Handbuch der Kirchengeschichte, edited by Josef Glazik et al. Basel: Herder, 1975, vol. 4, pp. 521-560.

15 For the term reenactment see Erika Fischer-Lichte. "Die Wiederholung als Ereignis: Reenactment als Aneignung von Geschichte." Theater als Zeitmaschine, edited by Ulf Otto et al. Bielefeld: Transcript, 2012, pp. 13-52.

16 The distinction made here is a heuristic one; as opposed to passion processions, passion procession plays are those that include dramatic texts. 
Škofja Loka in the first half of the eighteenth century [fig. 1]. These late performances reflect a tradition set up by the Capuchins one century previously on their missionary route from Innsbruck via Prague, Vienna, Graz, and Ljubljana. ${ }^{17}$ The Good Friday processions of Škofja Loka, however, are documented not only by way of periochae, or, as is often the case with these performances, in the form of procession orders. Rather, a whole codex has been preserved, containing, among other things, a complete dramatic manuscript with 841 lines and stage directions written by Friar Romuald of Štandrež.

In this text, which originates in the years $1725-1727^{18}$ and is called Škofjeloški pasijon (The Passion of Škofja Loka), ${ }^{19}$ the whole action is structured into 13 'figures' (lat. figurae), that is, into 13 scenes, each concentrating on one self-contained event, such as the Last Supper, Flagellation, or Coronation of Christ. $^{20}$ These scenes were enacted either on large supporting frames carried through the streets, or on carts pulled by horses, or they were simply performed on foot. Within the scenes, the main narrative was accompanied by many other elements, embedded into the procession as collective bodies: angels, penitents, cross-draggers, eremites, local guilds, musicians, townsmen, town councillors, and the clergy. The last segment of the procession consisted of the common people.

The example of the Škofjeloški pasijon allows us to develop a good idea of the auditory and visual impact the procession must have had on the audience. If one looks at the lines the performers were to recite, it is striking how often the characters engage the audience. In almost every scene, the spectator is addressed in a lordly, disciplinary manner; sometimes, indeed, as človek (man), but far more frequently as grešnik (sinner), grešni človek (man of sin), or grešna duša (sinner soul). For instance, in the very first scene, "Paradise" (lat. Paradisus), the Third Angel, who has just been witness to the Fall of Man, speaks out:

17 See Metod Benedik. Die Kapuziner in Slowenien: 1600-1750. Dissertation, Rome, Pontificia Universitas Gregoriana, 1973, pp. 51-63.

18 See Matija Ogrin. “Tradicija in datacija Škofjeloškega pasijona. Ekdotična perspektiva”. Škofjeloški pasijon, edited by Matija Ogrin. Celje: Celjska Mohorjeva družba, 2009, pp. 343-365.

19 The manuscript itself does not bear any title. On a note added later, which is now lost, was once written: "Instructio pro Processione Locopolitana in die Parasceve Dni. (3. Die Martii 1721.)” (see Oče Romuald. Škofjeloški pasijon, edited by Matija Ogrin. Celje: Celjska Mohorjeva družba, 2009, p. 327).

20 The scenes of the Škofjeloški pasijon are as follows: "Paradisus," "Mors," "Cæna Domini," a scene with Samson, "Sudor Sanguineus," "Flagelatio [sic] Christi," "Coronatio," a scene with Jerome, "Ecce Homo," “Christus in Cruce," "Mater Septem Dolorum,” "Archa Fæderis” and "Sepulchrum Domini”.

21 Oče Romuald. Škofjeloški pasijon, edited by Matija Ogrin. Celje: Celjska Mohorjeva družba, 2009, p. 178 f., emphasis mine. 
Grešna duša ti imaš poslušat, ja, tojga Boga nikar taku skušat. Ravnu tebi se ima tudi pərgoditi, kir ti se na masaš to pregreho sturiti. Zamoreš to nebešku kralestvu zgubiti inu ta paklenski ogenj zaslužiti.

Odstopi tedaj od te pregrehe, taku na prideš v te večne kehe. Glihi viži se s tem grešnikam zgodi, kateri zapovedi Božje na drži. ${ }^{21}$

The sinner soul, you have to listen you should not tempt your God in such a manner.

Precisely to you this may happen as well, since you do not refrain from sinning. You might lose the kingdom of heaven and deserve the infernal fire. Therefore, renounce your sin and in this way you will not come into the eternal jail. The same will happen to the sinners who will not keep the commandments. ${ }^{22}$

Only a few moments later, the Second Angel, who carries a moneybag, says:

O čudu čez vse čudesa, čudite se vi v nebesa! Srebrnikov trideseti oče Judas za Jezusa vzeti. Divica Marija bi ga na dala, za vas volni svet nikar na predala. Ti grešnik, ti ga pak predaš ter za en majhen lušt ga kjekaj daš. O grešnik, več, več je vreden! Le-to dobru ve eden sleden! Le-to, o grešnik, prov premisli ter močnu v srce pərtisni. [fig. 2] $]^{23}$

O wonder above all wonders, you may wonder to the heaven! Thirty silver coins Judas will take for Jesus. Virgin Mary would not give him away, she would not turn him over for the whole world.

22 Literal translation, emphasis mine.

23 Oče, Škofjeloški pasijon, p. 180. 


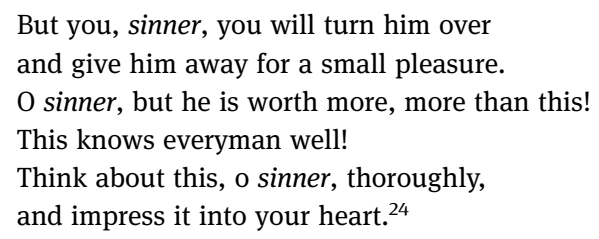

On the other hand, the highly visual effect of the performance of the Škofjeloški pasijon can be surmised from the very length of the procession. Given that between 300 and 600 people, or one third to one half of the resident population of Škofja Loka, participated in it, it must have functioned as an impressive, identity-generating "closed crowd." 25

While their main effect was produced in or during performance, Good Friday processions sometimes also resonated unintentionally beyond their initial frames. When Komploier in his sermon growls at the "reformers" who dared to hiss down the processions, his words may well have been aimed at the anticlerical satire of the time. Here, the most prominent example is the tract Specimen monachologiæ methodo Linnæana, written by a member of the Order of Illuminati, Ignaz von Born alias Johannes Physiophilius, in 1783, in which the religious orders are mocked as a species at the evolutionary level between monkey and man [fig. 3]. What is more, in Entwurf einer ländlichen Charfreytagsprocession, written by another Illuminatus, Anton von Bucher, in 1782, it is precisely the Good Friday processions that are under fire. Bucher attributed this book to the fictitious Pater Umgang (Father Procession), who in fear of the upcoming ban decides to sort out the best of many processions ("das beste heraus sortiren" ${ }^{26}$ ), and publish it for posterity. Yet what follows ${ }^{27}$ is more than 80 pages in which characters and scenes are subjected to a most alienating satirical treatment. For instance, the scene of the sacrament of baptism is presented by the guild of bartenders ("Bierzapfler" and "Geiwirthe"28), who walk along carrying a plate with the inscription: "'Er aber taufete im Wasser.' Joh. 2,5.”29 (“'He, however, baptized in water.' Jo. 2:5.”). Or, in another scene, the Jesuit missionaries, "voll christlicher Starkmuth" ("filled with Christian

24 Literal translation, emphasis mine.

25 Elias Canetti. Crowds and Power. New York: Continuum, 1981, p. 16-17.

26 Anton Bucher. Entwurf einer ländlichen Charfreytagsprocession: Samt einem gar lustigen und geistlichen Vorspiel zur Passionsaction. Munich: Fleischmann, 1782, p. 16.

27 In the preface, the narrator emphasizes that the text which follows was published exactly as delivered by Pater Umgang: "Ich habe nichts davon gethan, und nichts dazu." ("I did not remove or add anything.”) (Ibid., unpaginated.)

28 Ibid., p. 23.

29 Ibid., p. 24. 


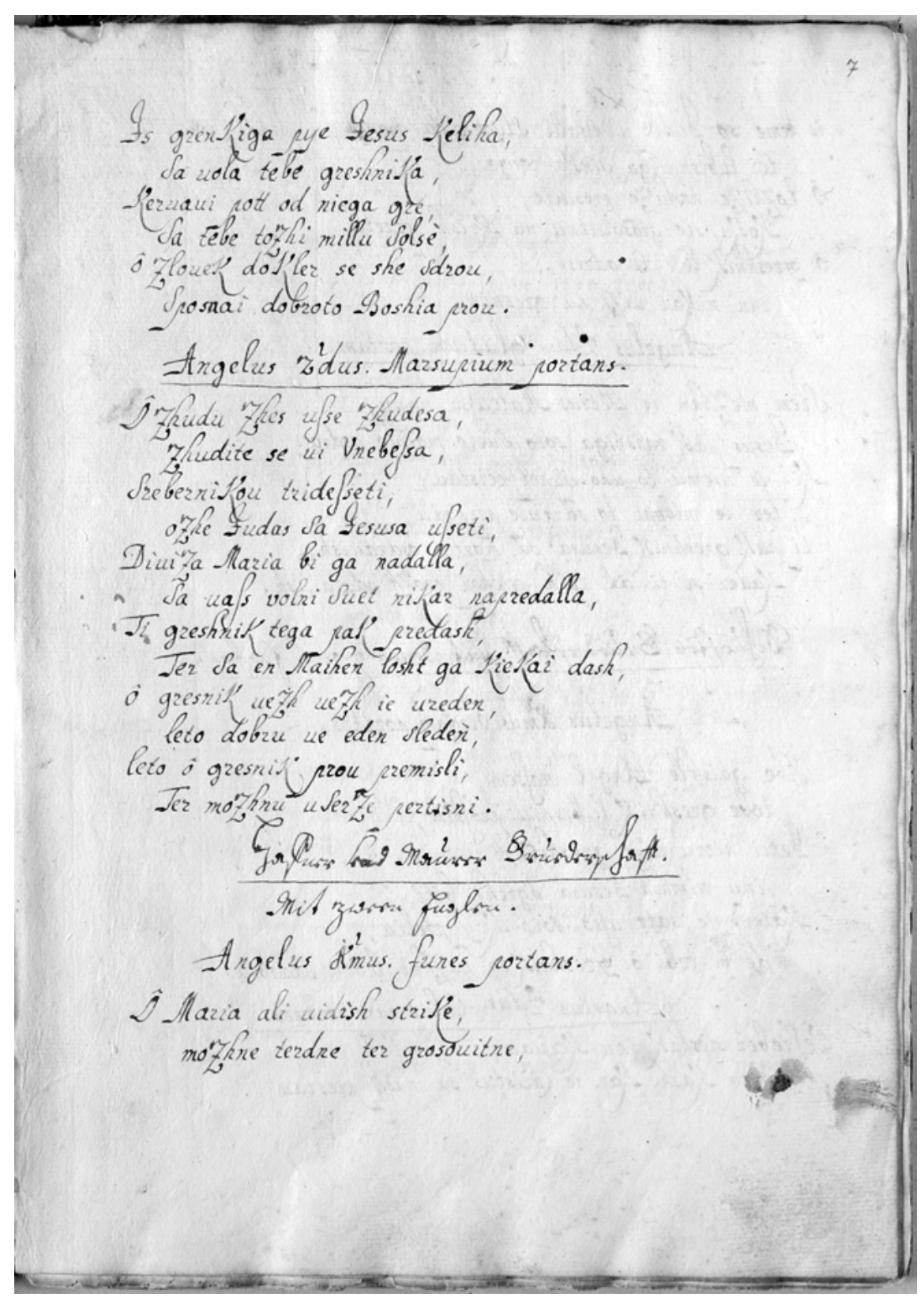

Fig. 2: The manuscript of the Škofjeloški pasijon (The Passion of Škofja Loka) from 1725-1727, fol. 7r. Slovenska kapucinska provinca, Kapucinski samostan Škofja Loka. 


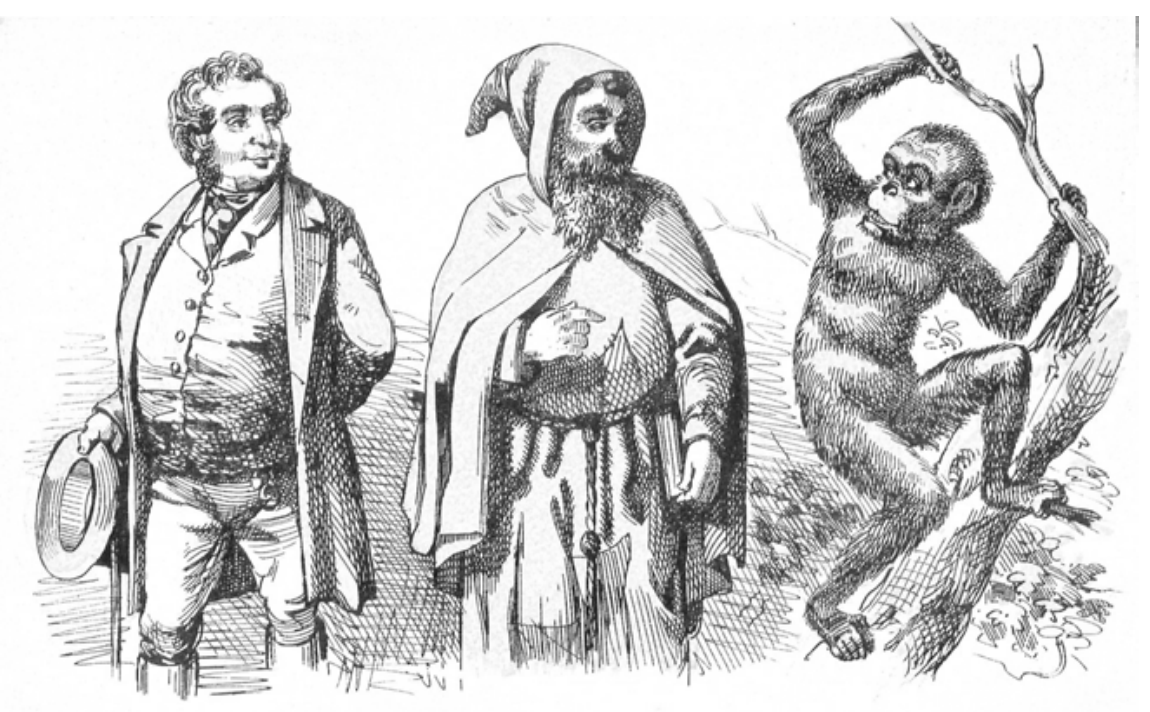

Fig. 3: A lithography made by Adam Arnst for the English edition of Johannes Physiophilius' tract Specimen monachologiæ methodo Linnæana from 1852.

courage"), who have been sent to India by the pope, are shown to strangle the unbelievers while reciting: "Die Götzenknecht und ihre Werke / Zuzernichten war unsere Stärke" 30 ("Our quality was to destroy / the idolaters and their works."). ${ }^{31}$ The fact that the Good Friday processions are parodied, that the authority of the genre is exposed to ridicule and undermined, leads to the conclusion that Bucher perceived them in terms of power relations. Precisely by entering "the most political part of all literature," 32 their political dimension became overt and explicit.

30 Ibid., p. 25.

31 Literal translation.

32 Matthew Hodgart. Satire. London: Weidenfels, 1969, p. 33. 